\title{
PENGKLASTERAN PROVINSI-PROVINSI DI INDONESIA BERDASARKAN INDIKATOR YANG MEMPENGARUHI INDEKS PEMBANGUNAN MANUSIA MENGGUNAKAN METODE FUZZY C-MEANS
}

\author{
DEBBY ARMETIYANA MARGARETTA, IZZATI RAHMI HG*, HAZMIRA YOZZA \\ Program Studi S1 Matematika, \\ Fakultas Matematika dan Ilmu Pengetahuan Alam, Universitas Andalas, \\ Kampus UNAND Limau Manis Padang, Indonesia. \\ email : debbyarmetiyana98@gmail.com,izzatirahmihg@sci.unand.ac.id, \\ hazmirayozza@sci.unand.ac.id
}

Diterima 15 Desember 2020 Direvisi 29 Desember 2020 Dipublikasikan 12 Januari 2021

\begin{abstract}
Abstrak. Analisis klaster merupakan salah satu teknik dalam analisis peubah ganda yang bertujuan untuk mengklasterkan objek-objek berdasarkan kesamaan karakteristik yang dimilikinya. Pengklasteran dilakukan berdasarkan pada sifat kemiripan atau sifat ketidakmiripan antar objek. Pada penelitian ini untuk mengklaster provinsi-provinsi di Indonesia berdasarkan faktor-faktor yang diduga mempengaruhi Indeks Pembangunan Manusia (IPM) digunakan salah satu metode dalam fuzzy clustering yaitu fuzzy c-means. Fuzzy c-means adalah suatu teknik pengklasteran data dimana keberadaan tiap-tiap titik data dalam klaster ditentukan oleh derajat keanggotaan. Berdasarkan hasil pengklasteran menggunakan fuzzy c-means diperoleh pengklasteran provinsi-provinsi di Indonesia sebanyak empat klaster, dimana klaster pertama terdiri atas 6 provinsi, klaster kedua terdiri atas 2 provinsi, klaster ketiga terdiri atas 12 provinsi, dan klaster keempat terdiri atas 14 provinsi. Berdasarkan karakteristik klaster, klaster pertama dikatakan klaster terbaik karena rata-rata pencapaian setiap indikatornya tinggi sedangkan klaster kedua merupakan klaster terendah dibanding klaster lainnya.
\end{abstract}

Kata Kunci: klaster, Indeks Pembangunan Manusia, Fuzzy C-Means

\section{Pendahuluan}

Hakikat pembangunan adalah upaya mewujudkan tujuan nasional bangsa Indonesia yang maju, mandiri dan berkeadilan. Hal ini diwujudkan dengan merumuskan suatu konsep baru dalam mengukur pembangunan yang berorientasi pada manusia yaitu Indeks Pembangunan Manusia (IPM). IPM merupakan tolak ukur keberhasilan pembangunan manusia yang mencakup tiga dimensi kehidupan manusia,

*penulis korespondensi 
yaitu kesehatan, pengetahuan, dan standar hidup layak [1]. Meskipun IPM di setiap provinsi di Indonesia berbeda-beda, tetapi ada beberapa provinsi yang memiliki kemiripan yang sama sehingga dapat dibuat suatu pengklasteran. Pengklasteran ini berdasarkan faktor-faktor yang diduga mempengaruhi nilai IPM.

Pengklasteran provinsi-provinsi di Indonesia menggunakan metode analisis klaster. Analisis klaster dibedakan menjadi dua metode, yaitu metode berhirarki dan metode takberhirarki. Metode tak berhirarki yang sering digunakan yaitu $K$ Means cluster [4]. Akan tetapi pada saat mendefenisikan keanggotaan suatu klaster yang tidak jelas batasannya atau tidak pasti maka pengklasteran dengan $K$-Means menjadi kurang tepat. Oleh karena itu muncul teori himpunan fuzzy yang mendasari berkembangnya metode fuzzy clustering. Metode fuzzy clustering memungkinkan suatu objek menjadi anggota dari suatu klaster atau lebih, sehingga menghasilkan pengklasteran yang lebih teliti [6]. Dalam fuzzy clustering, salah satu metode yang telah dikembangkan yaitu fuzzy c-means. Oleh karena itu dalam penelitian ini akan dilakukan pengklasteran provinsi-provinsi di Indonesia berdasarkan faktor-faktor yang diduga mempengaruhi IPM menggunakan metode fuzzy c-means.

\section{Landasan Teori}

\subsection{Analisis Klaster}

Analisis klaster merupakan salah satu teknik dalam analisis peubah ganda yang bertujuan untuk mengklasterkan objek-objek berdasarkan kesamaan karakteristik yang dimilikinya. Pengklasteran dilakukan berdasarkan pada sifat kemiripan atau sifat ketidakmiripan antar objek. Objek yang berada dalam klaster yang sama akan lebih mirip dibandingkan dengan objek pada klaster yang berbeda [2].

Pada prinsipnya analisis klaster didasarkan pada ukuran kemiripan atau ketidakmiripan dari setiap objek yang dinyatakan dalam fungsi jarak. Dalam analisis klaster terdapat beberapa ukuran jarak, diantaranya yaitu [2] :

(1) Jarak Euclidean

Perhitungan jarak euclidean adalah mencari jarak terpendek dari dua titik dengan prinsip orthogonal (tegak lurus). Jarak euclidean didefinisikan sebagai berikut

$$
d_{i j}=\sqrt{\sum_{k=1}^{p}\left(x_{i k}-x_{j k}\right)^{2}}
$$

(2) Jarak Manhattan

Formula jarak manhattan mencari jarak terpanjang atau jarak yang ditempuh oleh dua titik. Jarak manhattan didefinisikan sebagai berikut

$$
d_{i j}=\sum_{k=1}^{p}\left|x_{i k}-x_{j k}\right|
$$

\subsection{Fuzzy C-Means}

Fuzzy $C$-Means (FCM) adalah salah satu teknik pengklasteran data yang mana keberadaan tiap-tiap titik data dalam suatu klaster ditentukan oleh derajat keang- 
Pengklasteran Provinsi di Indonesia Berdasarkan IPM Menggunakan Fuzzy C-Means 81

gotaannya. Teknik ini pertama kali diperkenalkan oleh Jim Bezdek pada tahun 1981. Konsep dasar dari fuzzy c-means adalah menentukan pusat klaster yang akan menandai lokasi rata-rata untuk tiap-tiap klaster. Pada metode FCM pusat awal klaster masih belum akurat karena setiap data memiliki derajat keanggotaan untuk setiap klaster. Oleh karena itu, dilakukan perulangan untuk memperbaiki pusat klaster dan derajat keanggotaan sehingga pusat klaster akan bergerak menuju lokasi yang tepat. Perulangan ini didasarkan pada minimalisasi fungsi objektif yang menggambarkan jarak antara data ke pusat klaster [3].

Berikut adalah algoritma fuzzy c-means [3] :

(1) Menentukan data yang akan diklaster berupa matriks $\mathbf{X}_{i j}$ yaitu data sampel ke- $i(i=1,2, \ldots, n)$, peubah ke- $j(j=1,2, \cdots, m)$.

(2) Menentukan nilai parameter awal yaitu jumlah klaster $(c)$, pangkat pembobot $(w>1)$, dan fungsi objektif awal $J_{F C M}(U, V)^{0}=0$.

(3) Menentukan maksimum iterasi dan error terkecil yang diharapkan $(\xi)$.

(4) Membangkitkan bilangan random $\mu_{i k}, i=1,2, \cdots, n ; k=1,2, \cdots, c$; sebagai elemen-elemen matriks partisi awal U. Matriks partisi pada pengklasteran fuzzy memenuhi kondisi sebagai berikut $\mu_{i k} \in[0,1]$ dan $\sum_{k=1}^{c} \mu_{i k}=1$.

(5) Menghitung pusat klaster ke $-k\left(V_{k j}\right), k=1,2, \cdots, c$ dan $j=1,2, \cdots, m$

$$
V_{k j}=\frac{\sum_{i=1}^{n}\left(\left(\mu_{i k}\right)^{w}\left(X_{i j}\right)\right.}{\sum_{i=1}^{n}\left(\mu_{i k}\right)^{w}}
$$

(6) Menghitung fungsi objektif pada iterasi ke- $t\left(J_{F C M}(U, V)^{t}\right)$.

$$
J_{F C M}(U, V)^{t}=\sum_{i=1}^{n} \sum_{k=1}^{c}\left(\left[\sum_{j=1}^{m}\left(X_{i j}-V_{k j}\right)^{2}\right]\left(\mu_{i k}\right)^{w}\right)
$$

(7) Menghitung perubahan matriks partisi.

$$
\mu_{i k}=\frac{\left[\sum_{j=1}^{m}\left(X_{i j}-V_{k j}\right)^{2}\right]^{\frac{-1}{w-1}}}{\sum_{k=1}^{c}\left[\sum_{j=1}^{m}\left(X_{i j}-V_{k j}\right)^{2}\right]^{\frac{-1}{w-1}}}
$$

(8) Memeriksa kondisi berhenti, jika $\left|J_{F C M}(U, V)^{t}-J_{F C M}(U, V)^{t-1}\right|<\xi$ atau $t>$ maksimum iterasi maka iterasi berhenti, jika tidak maka $t=t+1$ dan mengulang kembali ke langkah 5.

\subsection{Validitas Klaster}

Pada metode fuzzy terdapat dua kategori untuk menghitung indeks validitas klaster yaitu berdasarkan nilai keanggotaan dan menggunakan data itu sendiri. Salah satu indeks validitas yang hanya melibatkan nilai keanggotaan adalah indeks Modified Partition Coefficient (MPC). MPC merupakan indeks validitas hasil perbaikan dari 
metode Partition Coefficient (PC). Metode PC cenderung mengalami perubahan yang monoton terhadap nilai $c$. Nilai MPC didefinisikan dengan persamaan

$$
M P C=1-\frac{c}{c-1}(1-P C)
$$

Adapun persamaan indeks PC yaitu

$$
P C=\frac{1}{n} \sum_{k=1}^{c} \sum_{i=1}^{n}\left(\mu_{i k}\right)^{2}
$$

dengan $n$ adalah banyak objek penelitian, $c$ adalah banyak klaster, dan $\mu_{i k}$ adalah nilai keanggotaan objek ke- $i$ pada klaster ke- $k$.

Nilai MPC berkisar antara $0 \leq \mathrm{MPC} \leq 1$. Penentuan hasil klaster optimal dari beberapa jumlah klaster yang dihasilkan ditentukan dari nilai MPC yang terbesar $[5]$.

\section{Metode Penelitian}

Data yang digunakan dalam penelitian ini adalah data sekunder mengenai faktorfaktor yang mempengaruhi indeks pembangunan manusia di provinsi-provinsi di Indonesia pada tahun 2018. Data yang digunakan dalam penelitian ini bersumber dari data Badan Pusat Statistik 2018 dalam bidang sosial dan kependudukan.

Peubah yang digunakan dalam penelitian ini adalah angka harapan hidup saat lahir $\left(X_{1}\right)$, angka melek huruf $\left(X_{2}\right)$, rata-rata lama sekolah $\left(X_{3}\right)$, akses terhadap hunian layak dan terjangkau $\left(X_{4}\right)$, sumber air minum layak dan berkelanjutan $\left(X_{5}\right)$, tingkat pengangguran terbuka $\left(X_{6}\right)$, kemiskinan $\left(X_{7}\right)$, dan tenaga kerja formal $\left(X_{8}\right)$.

Tahap-tahap yang dilakukan adalah :

(1) Melakukan pengklasteran menggunakan algoritma fuzzy c-means.

(2) Menentukan jumlah klaster optimum menggunakan indeks validitas Modified Partition Coefficient (MPC).

(3) Menentukan anggota klaster optimum menggunakan derajat keanggotaan.

(4) Interpretasi hasil pengklasteran dan karakteristik klaster.

\section{Pembahasan}

\subsection{Jumlah Klaster Optimum}

Penentuan jumlah klaster terbaik dapat dilihat berdasarkan nilai indeks validitas klaster. Indeks validitas klaster yang digunakan yakni indeks MPC. Pada MPC mengindikasikan bahwa nilai yang terbesar merupakan nilai yang optimal. Hasil indeks validitas klaster dengan metode fuzzy c-means untuk tiap kemungkinan jumlah klaster dapat dilihat pada Tabel 1.

Berdasarkan Tabel 1, nilai indeks MPC tertinggi pada metode fuzzy c-means ialah dengan jumlah empat klaster. Nilainya adalah 0.3961077. Berdasarkan hal tersebut, jumlah klaster yang optimal untuk digunakan adalah sebanyak empat klaster. 
Tabel 1. Nilai MPC

\begin{tabular}{|c|c|}
\hline Jumlah Klaster & MPC \\
\hline $\mathbf{3}$ & 0.3284575 \\
\hline $\mathbf{4}$ & 0.3961077 \\
\hline $\mathbf{5}$ & 0.3675047 \\
\hline $\mathbf{6}$ & 0.3368442 \\
\hline $\mathbf{7}$ & 0.3662086 \\
\hline
\end{tabular}

\subsection{Hasil Pengklasteran Menggunakan Fuzzy C-Means}

\subsubsection{Hasil Pengklasteran}

Setelah klaster optimal diperoleh, akan ditentukan keanggotaan pada setiap klaster optimal didasarkan pada derajat keanggotaan yang dapat dilihat pada Tabel 2.

Tabel 2. Derajat Keanggotaan Setiap Provinsi untuk 4 Klaster

\begin{tabular}{|c|l|c|c|c|c|}
\hline No & Provinsi & Klaster $\mathbf{1}$ & Klaster 2 & Klaster 3 & Klaster 4 \\
\hline 1. & Aceh & 0.04099452 & 0.051194189 & 0.07759571 & $\mathbf{0 . 8 3 0 2 1 5 5 8}$ \\
\hline 2. & Sumatera Utara & 0.09958408 & 0.018361282 & $\mathbf{0 . 7 4 9 9 2 9 5 1}$ & 0.13212512 \\
\hline 3. & Sumatera Barat & 0.07546873 & 0.016246945 & $\mathbf{0 . 8 4 0 1 0 9 7 9}$ & 0.06817454 \\
\hline 4. & Riau & 0.31576198 & 0.016158784 & $\mathbf{0 . 5 9 5 7 7 4 2 4}$ & 0.07230500 \\
\hline 5. & Jambi & 0.08601564 & 0.016428153 & $\mathbf{0 . 7 9 8 5 5 1 3 5}$ & 0.0900485 \\
\hline$\ldots$ & $\ldots$ & $\ldots$ & $\ldots$ & $\ldots$ & $\ldots$ \\
\hline 31. & Maluku & 0.07400095 & 0.178525163 & 0.11188272 & $\mathbf{0 . 6 3 5 5 9 1 1 7}$ \\
\hline 32. & Maluku Utara & 0.11430122 & 0.030154438 & $\mathbf{0 . 7 4 8 5 6 9 1 0}$ & 0.10697524 \\
\hline 33. & Papua Barat & 0.12263172 & 0.296151954 & 0.14444648 & $\mathbf{0 . 4 3 6 7 6 9 8 5}$ \\
\hline 34. & Papua & 0.04637383 & $\mathbf{0 . 7 7 8 3 0 2 4 1 4}$ & 0.06276563 & 0.11255812 \\
\hline
\end{tabular}

Dari derajat keanggotaan setiap provinsi dapat dilihat kecenderungan provinsi untuk masuk ke klaster mana. Derajat keanggotaan terbesar menunjukkan bahwa kecenderungan tertinggi suatu provinsi untuk masuk menjadi anggota klaster tersebut. Misalnya untuk Provinsi Aceh, dapat menjadi anggota klaster ke-1 dengan derajat keanggotaan 0.04099452, anggota klaster ke-2 dengan derajat keanggotaan 0.051194189 , anggota klaster ke-3 dengan derajat keanggotaan 0.07759571, dan anggota klaster ke-4 dengan derajat keanggotaan 0.83021558. Derajat keanggotaan terbesarnya terletak di klaster keempat, maka Provinsi Aceh akan dimasukkan kedalam klaster keempat.

Dengan demikian hasil pengklasteran untuk klaster optimal dapat dilihat pada Tabel 3. 
Debby Armetiyana Margaretta dkk.

Tabel 3. Hasil Pengklasteran Provinsi di Indonesia Menggunakan FCM

\begin{tabular}{|l|l|}
\hline Klaster & Nama Provinsi \\
\hline Klaster 1 & Kepulauan Riau, DKI Jakarta, Banten, Bali, Kalimantan Timur, Kalimantan Utara \\
\hline Klaster 2 & NTT, Papua \\
\hline Klaster 3 & $\begin{array}{l}\text { Sumatera Utara, Sumatera Barat, Riau, Jambi, Kepulauan Bangka Belitung, } \\
\text { Jawa Barat, Kalimantan Barat, Kalimantan Tengah, Kalimantan Selatan, } \\
\text { Klaster 4 }\end{array}$ \\
$\begin{array}{l}\text { Aceh, Sumatera Selatan, Bengkulu, Lampung, Jawa Tengah, } \\
\text { DI Yogyakarta, Jawa Timur, NTB, Sulawesi Tengah, } \\
\text { Sulawesi Tenggara, Gorontalo, Sulawesi Barat, } \\
\text { Maluku, Papua Barat }\end{array}$ \\
\hline
\end{tabular}

\subsubsection{Karakteristik Klaster}

Setelah klaster terbentuk, diambil rata-rata dari masing-masing faktor-faktor IPM terhadap seluruh objek penelitian (34 provinsi di Indonesia), dimana faktor-faktor tersebut yaitu AHH, AMH, RLS, akses terhadap hunian layak dan terjangkau, sumber air minum layak, tingkat pengangguran terbuka, kemiskinan, dan tenaga kerja formal $(\bar{X})$. Selanjutnya untuk masing-masing klaster juga diambil rata-rata untuk AHH, AMH, RLS, akses terhadap hunian layak dan terjangkau, sumber air minum layak, tingkat pengangguran terbuka, kemiskinan, dan tenaga kerja formal $\left(\bar{X}_{c}\right)$. Pada setiap peubah didalam klaster diberi tanda, jika $\bar{X}_{c}>\bar{X}$ maka diberi tanda positif $(+)$, sedangkan jika $\bar{X}_{c}<\bar{X}$ maka diberi tanda negatif (-). Adapun karakteristik hasil pengklasteran disajikan pada Tabel 4.

Tabel 4. Karakteristik Hasil Pengklasteran Provinsi di Indonesia

\begin{tabular}{|c|c|c|c|c|c|c|c|c|}
\hline Klaster & $X_{1}$ & $X_{2}$ & $X_{3}$ & $X_{4}$ & $X_{5}$ & $X_{6}$ & $X_{7}$ & $X_{8}$ \\
\hline Klaster 1 & + & + & + & + & + & + & - & + \\
\hline Klaster 2 & - & - & - & - & - & - & + & - \\
\hline Klaster 3 & + & - & + & + & - & + & - & + \\
\hline Klaster 4 & - & - & - & + & - & - & + & - \\
\hline
\end{tabular}

Pada penelitian ini, diberikan asumsi bahwa jika peubah angka harapan hidup sejak lahir $\left(X_{1}\right)$, angka melek huruf $\left(X_{2}\right)$, rata-rata lama sekolah $\left(X_{3}\right)$, akses terhadap hunian layak dan terjangkau $\left(X_{4}\right)$, sumber air minum layak dan berkelanjutan $\left(X_{5}\right)$, dan persentase tenaga kerja $\left(X_{8}\right)$ bernilai positif atau rata-rata klasternya lebih tinggi dibandingkan rata-rata peubah, maka dapat dikatakan bahwa tingkat keberhasilan pembangunan pada klaster tersebut relatif lebih baik. Sedang- 
kan untuk peubah tingkat pengangguran terbuka $\left(X_{6}\right)$ dan kemiskinan $\left(X_{7}\right)$ jika bernilai negatif atau rata-rata klasternya lebih rendah dibandingkan rata-rata peubah maka dapat dikatakan tingkat keberhasilan pembangunannya relatif lebih baik pada klaster tersebut.

Berdasarkan Tabel 4 terlihat bahwa pada Klaster 1 hampir semua peubah dapat dikatakan tingkat keberhasilan pembangunannya baik, kecuali pada peubah tingkat pengangguran terbuka $\left(X_{6}\right)$. Pada Klaster 2 hampir semua peubah tingkat keberhasilan pembangunannya relatif kurang baik. Pada klaster ini hanya peubah tingkat pengangguran terbuka $\left(X_{6}\right)$ yang dapat dikatakan tingkat keberhasilan pembangunannya sudah relatif baik. Pada Klaster 3 peubah yang tingkat keberhasilan pembangunannya relatif kurang baik yaitu angka melek huruf $\left(X_{2}\right)$, sumber air minum layak dan berkelanjutan $\left(X_{5}\right)$, dan tingkat pengangguran terbuka $\left(X_{6}\right)$. Pada Klaster 4 peubah yang tingkat keberhasilan pembangunannya relatif kurang baik yaitu angka harapan hidup sejak lahir $\left(X_{1}\right)$, angka melek huruf $\left(X_{2}\right)$, rata-rata lama sekolah $\left(X_{3}\right)$, sumber air minum layak dan berkelanjutan $\left(X_{5}\right)$, kemiskinan $\left(X_{7}\right)$, dan persentase tenaga kerja $\left(X_{8}\right)$.

\section{Kesimpulan}

Berdasarkan hasil penelitian pengklasteran provinsi-provinsi di Indonesia menggunakan metode fuzzy c-means menghasilkan empat klaster. Hasil pengklasteran yang diperoleh sesuai dengan angka IPM masing-masing provinsi, dimana provinsi yang memiliki angka IPM rendah berada pada klaster yang sama dan begitu sebaliknya. Berdasarkan karakteristik klaster, secara umum Klaster 1 dapat dikatakan klaster terbaik dibanding klaster lainnya karena hanya satu indikator yang perlu mendapat perhatian lebih. Klaster 2 dapat dikatakan sebagai klaster terendah dibanding klaster lainnya, karena hampir semua indikator rata-rata pencapaian untuk tiap indikatornya rendah. Ini menyebabkan bahwa pada Klaster 2 banyak indikator yang harus mendapat perhatian lebih dalam meningkatkan indeks pembangunan manusia di Indonesia.

\section{Ucapan Terima kasih}

Penulis mengucapkan terimakasih kepada Ibu Dr. Ferra Yanuar, Bapak Budi Rudianto M.Si dan Bapak Efendi M.Si yang telah memberikan masukan dan saran sehingga paper ini dapat diselesaikan dengan baik.

\section{Daftar Pustaka}

[1] Badan Pusat Statistik. 2018. Indeks Pembangunan Manusia tahun 2018. BPS : Jakarta.

[2] Johnson R, D.Wichern. 2007. Applied Multivariate Statistical Analysis, Sixth Edition. Pearson Education : New Jersey.

[3] Kusumadewi dan Purnomo .2004. Aplikasi Logika Fuzzy untuk Pendukung Keputusan. Graha Ilmu : Yogyakarta.

[4] Mattjik AA, Sumertajaya IM. 2011. Sidik Peubah Ganda dengan Menggunakan SAS Edisi Pertama. Departemen Statistika FMIPA IPB : Bogor. 
86 Debby Armetiyana Margaretta dkk.

[5] Xie, N., L.Hu, N.Luktarhan, dan K.Zhao. 2011. A Classification of Cluster Validity Indexes Based on Membership Degree and Aplication. Web Information System and Mining. $43-50$.

[6] Yang MS. 1993. A Survey of Fuzzy Clustering. Math. Comput Modelling. 18(11): $1-16$. 